\title{
Impact of Basic Training Programme On Medical Teachers - A Useful Pathway To Success
}

\section{IJCRR}

Section: Healthcare

Sci. Journal Impact

Factor: 6.1 (2018)

ICV: 90.90 (2018)

\section{Aruna Kharkar ${ }^{1}$, Suvarna Gulanikar ${ }^{2 *}$, Anirudha Gulanikar ${ }^{3}$, G.A. Shroff ${ }^{4}$}

'Professor Emirates and head MEU, MGM MC, Aurangabad; 'Assistant Professor, Department of Anatomy, MGM MC, Aurangabad; ${ }^{3}$ Associate Professor Dept. of Dermatology MGM MC, Aurangabad; 4 Professor and head, Dept. of Anatomy MGM MC Aurangabad

\section{ABSTRACT}

Objectives: Change in concept of medical education from the traditional to the new learning styles needs more Workshops on Medical education for refreshing the knowledge of medical teachers. Main objective of our research was to assess medical teachers before and after Medical Education training. Research is based on a retrospective questionnaire-based study.

Method: Basic medical education workshops were conducted on 16 to 18 April 2013, 7 to 9 January 2014, 29 September to 1 October 2014, 17 to 19 March 2015 and 11 to 12 February 2020 at MEU, MGM Medical College, Aurangabad, Maharashtra. Total of 140 faculties from various departments participated in workshops. Each participant filled a pre-test questionnaire before the beginning of workshop and a post-test questionnaire after the completion of workshop. Scores obtained in the pre and posttest were compared. Each workshop conducted for eight hours per day for three days and participants gave effective feedback at the end of workshop.

Result: Statistical analysis suggests the significant improvement in the knowledge of participants [P=<0.003] after the workshop. $100 \%$ Participants gave feedback that workshop was very useful, while $96.42 \%$ responses suggest that the workshop's objective was achieved. $>90 \%$ replied that it was well planned, interactive and time-bound, had responsive, expert faculties and wants frequent organisation of such workshops in future.

Conclusion: Organisation of medical education workshop at regular interval for the medical teachers is required to keep them updated with the new advances in Medical Education.

Key Words: Feedback, Medical Education, Pre-test, Post-test, Workshop

\section{INTRODUCTION}

Medical education is a demanding task. In the recent years there has been a change in the concept of medical education from the traditional to the new learning styles; therefore, high quality medical education programmes for faculty members have become essential to all medical institutions. ${ }^{1}$

With the increasing number of medical colleges, there is a shortage of train medical teachers. In India Medical Education was started in the late seventies. In 1999 Medical council of India has made it mandatory to establish medical education technology unit [MET] in every medical college. MCI made every Medical Professional mandatory, to undergo at least the basic level of training from $2010 .^{2}$

In recent years, with the use of new teaching and learning methods, the focus of assessment has been shifted to the use of higher cognitive abilities, communication skills, and pro- fessionalism. Focus is also shifting from competency-based education to outcome-based education and workplace performance assessment. ${ }^{3}$ Here comes the role of Basic Medical Education workshops.

Recent advances in medical field have been understood and adapted in most of the medical colleges, but in practice, the methods and strategies are not systematically planned as per need of society. Medical education unit will help guide the medical teachers in experimenting, modulating, and implementing innovative technologies. This will prepare the present and future generation of medical teachers to be more effective in providing information, assessing students, curriculum planning and its implementation to produce the physician of first contact in society.

In current scenario of exploding knowledge, certain revisions are required in the format from time to time to make it more useful and acceptable both to the teachers and learners. These

\section{Corresponding Author:}

Dr. Suvarna Gulanikar, Assistant Professor, Department of Anatomy, Executive Member, MEU MGM MC, Aurangabad, Email: suvarnagulanikar@gmail.com

ISSN: 2231-2196 (Print)

Received: 24.04 .2020
ISSN: $0975-5241$ (Online)

Revised: 02.06 .2020
Accepted: 21.06 .2020 
revisions are based on the experience gained at previous workshops as well as from feedback given by the participants and faculty members. ${ }^{4,5}$ These workshops help to implement new teaching and learning methods and more focus to be given in the innovative teaching-learning methods as suggested by MCI..

The key to successful initiation and implementation to meet the needs of medical education is to develop the train faculties. So the training programmes for MGM medical college faculties, Aurangabad were organised, and the effect of training was evaluated. Main objective of this project was to observe the improvement in teaching-learning methodology of medical faculty before and after the workshop.

\section{MATERIAL AND METHODS}

Five consecutive workshops on basic medical education were conducted on 16 to 18 April 2013, 7 to 9 January 2014, 29 September to 1 October 2014, 17 to 19 March 2015 and 11 to 12 February 2020 at MEU, MGM Medical College, Aurangabad, Maharashtra. These workshops were guided and observed by faculty from nodal centre of medical education unit, KEM, Mumbai and faculty from Maharashtra medical council.

Total 140 faculties participated in five training programme. Participants were Professor, AssociateProfessor and Assistant Professor from preclinical, Para clinical and clinical department. Random selection of participants was done for each session. Training sessions were interactive and conducted by facilitators from various departments and $\mathrm{MCI}$ observer.

Table 1: Number of participants attended each workshop

\begin{tabular}{lc} 
Workshop conducted & Total No. of Participants \\
\hline April 2013 & 33 \\
January 2014 & 28 \\
September 2014 & 30 \\
March 2015 & 18 \\
February 2020 & 31 \\
\hline
\end{tabular}

Three days' workshop of 8 hours per day arranged, where various activity sessions conducted and participant's skill assessment done. In all workshops, 30 questions are asked in pre-test and post-test except in 2020 workshop where we kept selective 20 questions.

To assess each faculty's present knowledge about all aspects of teaching learning methodologies, a pre-test was conducted on first day before starting the session. On the last day by the end of workshop participant filled a post-test form, which was exactly same as of pre-test. They also filled feedback form about each session of workshop. We use Likert scale to assess questionnaire. Cognitive, psychomotor and affective all three domains of learning were taken care of in workshop schedule. Each workshop includes sessions on teaching-learning methodology, curriculum planning, assessment skills, OSCE[Objective Structured Clinical Examination] ,OSPE[Objective Structured Practical Examination], group dynamics, setting of paper, concept of blueprinting, use of media and feedback process.

The responses from participants were expressed in two graphs in following way.

1. A questionnaire survey of participants in pre-test and post-test were assessed to determine their degree of improvement in knowledge regarding medical education.

2. To evaluate their perception about the usefulness of workshop. Three-point Likert scale and responses to open-ended questions were used.

\section{RESULTS}

The questionnaire was designed taking into account various modalities of teaching and learning in medical education, including newer methodologies like curricular reforms, problem- based learning, early clinical exposure [ECE], OSCE and OSPE. These scores were then compared with post-test questionnaire scores. There was a significant improvement in the scores of the participants in the post-test questionnaire as compared to pre-test in all the aspects during all workshops.

Table 2: Retrospective pre-test and post-test evaluation- Table shows Correct answer of each question given by number of participants.[n=total no. of participants]

\begin{tabular}{|c|c|c|c|c|c|c|c|c|c|c|}
\hline \multirow{3}{*}{$\begin{array}{l}\text { Q. } \\
\text { no. }\end{array}$} & \multicolumn{2}{|c|}{$\begin{array}{l}\text { April- } \\
2013\end{array}$} & \multicolumn{2}{|c|}{$\begin{array}{c}\text { January- } \\
2014\end{array}$} & \multicolumn{2}{|c|}{$\begin{array}{c}\text { September- } \\
2014\end{array}$} & \multicolumn{2}{|c|}{$\begin{array}{c}\text { March } \\
2015\end{array}$} & \multicolumn{2}{|c|}{ February } \\
\hline & corl & $\begin{array}{l}\text { answer } \\
=33]\end{array}$ & corr & $\begin{array}{l}\text { answer } \\
=28]\end{array}$ & & $\begin{array}{l}\text { answer } \\
=30]\end{array}$ & cor & $\begin{array}{l}\text { answer } \\
8]\end{array}$ & cor & $\begin{array}{l}\text { answer } \\
=31]\end{array}$ \\
\hline & $\begin{array}{l}\text { Pre } \\
\text { test }\end{array}$ & post test & Pre test & post test & $\begin{array}{l}\text { Pre } \\
\text { test }\end{array}$ & post test & $\begin{array}{l}\text { pre } \\
\text { test }\end{array}$ & post test & $\begin{array}{l}\text { pre } \\
\text { test }\end{array}$ & post test \\
\hline 1 & 13 & 23 & 13 & 21 & 7 & 18 & 8 & 9 & 16 & 22 \\
\hline 2 & 16 & 17 & 14 & 26 & 16 & 17 & 11 & 12 & 18 & 28 \\
\hline
\end{tabular}


Table 2: (Continued)

\begin{tabular}{|c|c|c|c|c|c|c|c|c|c|c|}
\hline \multirow[t]{2}{*}{$\begin{array}{l}\text { Q. } \\
\text { no. }\end{array}$} & \multicolumn{2}{|c|}{$\begin{array}{l}\text { April- } \\
2013 \\
\text { correct answer } \\
{[n=33]}\end{array}$} & \multicolumn{2}{|c|}{$\begin{array}{c}\text { January- } \\
2014 \\
\text { correct answer } \\
{[n=28]}\end{array}$} & \multicolumn{2}{|c|}{$\begin{array}{l}\text { September- } \\
2014 \\
\text { correct answer } \\
{[\mathrm{n}=30]}\end{array}$} & \multicolumn{2}{|c|}{$\begin{array}{l}\text { March } \\
2015 \\
\text { correct answer } \\
{[n=18]}\end{array}$} & \multicolumn{2}{|c|}{$\begin{array}{c}\text { February } \\
2020 \\
\text { correct answer } \\
{[\mathbf{n}=31]}\end{array}$} \\
\hline & $\begin{array}{l}\text { Pre } \\
\text { test }\end{array}$ & post test & Pre test & post test & $\begin{array}{l}\text { Pre } \\
\text { test }\end{array}$ & post test & $\begin{array}{l}\text { pre } \\
\text { test }\end{array}$ & post test & $\begin{array}{l}\text { pre } \\
\text { test }\end{array}$ & post test \\
\hline 3 & 26 & 20 & 26 & 26 & 25 & 26 & 9 & 12 & 20 & 30 \\
\hline 4 & 30 & 23 & 18 & 25 & 21 & 24 & 11 & 14 & 16 & 18 \\
\hline 5 & 10 & 7 & 7 & 12 & 16 & 23 & 7 & 12 & 11 & 28 \\
\hline 6 & 13 & 17 & 10 & 21 & 11 & 16 & 7 & 14 & 11 & 26 \\
\hline 7 & 17 & 13 & 13 & 24 & 19 & 25 & 9 & 14 & 4 & 8 \\
\hline 8 & 17 & 20 & 7 & 17 & 9 & 22 & 6 & 15 & 5 & 14 \\
\hline 9 & 17 & 20 & 11 & 12 & 7 & 10 & 3 & 10 & 12 & 14 \\
\hline 10 & 20 & 17 & 6 & 10 & 9 & 22 & 7 & 11 & 14 & 26 \\
\hline 11 & 7 & 26 & 8 & 10 & 5 & 17 & 2 & 13 & 10 & 24 \\
\hline 12 & 12 & 23 & 18 & 22 & 18 & 25 & 4 & 11 & 7 & 10 \\
\hline 13 & 16 & 17 & 14 & 21 & 17 & 18 & 11 & 12 & 14 & 19 \\
\hline 14 & 13 & 17 & 7 & 11 & 15 & 25 & 3 & 10 & 8 & 20 \\
\hline 15 & 7 & 10 & 4 & 7 & 5 & 18 & 9 & 11 & 18 & 22 \\
\hline 16 & 10 & 10 & 1 & 7 & 20 & 24 & 11 & 11 & 25 & 30 \\
\hline 17 & 17 & 7 & 4 & 8 & 5 & 13 & 6 & 10 & 21 & 30 \\
\hline 18 & 13 & 23 & 16 & 17 & 10 & 16 & 6 & 9 & 13 & 20 \\
\hline 19 & 20 & 20 & 18 & 23 & 24 & 27 & 9 & 14 & 20 & 26 \\
\hline 20 & 5 & 12 & 2 & 6 & 11 & 12 & 3 & 10 & 7 & 30 \\
\hline 21 & 17 & 20 & 18 & 24 & 19 & 29 & 13 & 14 & - & - \\
\hline 22 & 4 & 12 & 4 & 10 & 15 & 16 & 6 & 10 & - & - \\
\hline 23 & 26 & 27 & 17 & 21 & 19 & 27 & 11 & 15 & - & - \\
\hline 24 & 23 & 23 & 19 & 21 & 8 & 12 & 4 & 9 & - & - \\
\hline 25 & 4 & 10 & 12 & 17 & 10 & 25 & 4 & 11 & - & - \\
\hline 26 & 26 & 27 & 13 & 23 & 5 & 11 & 3 & 5 & - & - \\
\hline 27 & 11 & 13 & 12 & 13 & 13 & 21 & 7 & 12 & - & - \\
\hline 28 & 16 & 17 & 3 & 4 & 10 & 15 & 5 & 10 & - & - \\
\hline 29 & 4 & 12 & 6 & 6 & 3 & 9 & 7 & 9 & - & - \\
\hline 30 & 20 & 23 & 17 & 20 & 15 & 21 & 11 & 18 & - & - \\
\hline
\end{tabular}




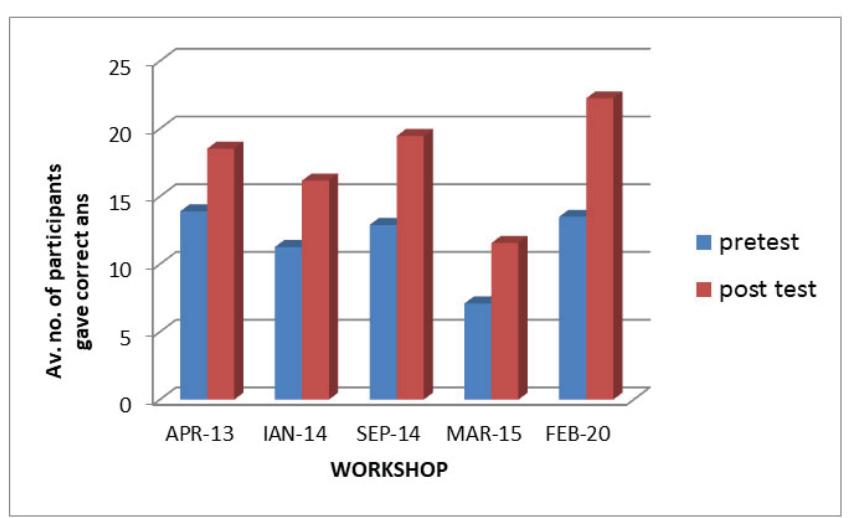

Graph 1: Comparison of pretest and post test in all 5 workshops

Table 3: Average Pre-test and post-test scores with 'P 'value of each workshop

\begin{tabular}{llccc} 
S. no. & Workshop & $\begin{array}{c}\text { Av. Pre } \\
\text { test } \\
\text { score }\end{array}$ & $\begin{array}{c}\text { Av. Post } \\
\text { test score }\end{array}$ & P-value \\
1. & March-13 & 13.9 & 18.53 & 0.000001 \\
2. & Jan- 14 & 11.26 & 16.16 & 0.00000000027 \\
3. & Sept.-14 & 12.9 & 19.46 & 0.0000011 \\
4. & March- 15 & 7.1 & 11.56 & 0.00114 \\
5. & Feb- 20 & 13.5 & 22.25 & 0.00314 \\
\hline
\end{tabular}

Average number of participants gave correct answers in pretest and post-test were compared of all the 5 workshops. Graph-1 shows that post-test score is much higher than pretest score in each workshop. Table-1 shows The $\mathrm{P}$ value which is $<0.001$ in first 4 workshops, while in last workshop value is 0.003 suggest significant correlation between pretest and post-test scores. It suggests that there is significant improvement in knowledge of each participant at the end of each workshop.

In programme evaluation questionnaire, it has been found that $96.42 \%$ of participants accepted that the objectives of the workshop were achieved. $100 \%$ participants replied that the workshop was useful. 'YES' response given by $94.28 \%$ participants for their active participation in workshop, by $92.85 \%$ participants for the usefulness of learning resources, and by $95.71 \%$ participants for responsive and helpful faculties. $100 \%$ participants asked for revisions of such workshops at regular intervals. $92.85 \%, 90 \%$ and $95.71 \%$ participants gave 'Good' response for time management, audio-visual and venue arrangement, while $64.28 \%$ of participants replied for proportional balance between theory and practical aspect of workshop.

Feedback of participants suggests that workshop was well planned, precise and time bound with lots of group activities. The overall impression about faculty speakers was very positive. They want more elaborative sessions on CBME in future.

\section{DISCUSSION}

A study conducted by Dr. Ajay Gaur et al showed that total of 74 participants attended the 3 consecutive workshops conducted in Department of Paediatrics, Gajra Raja Medical College, and Gwalior. Here post-evaluation questionnaires filled immediately and after three-months showed significant improvements in fields like objective assessment and

Table 4: Programme evaluation questionnaire [total no. of participants [ $\mathrm{n}=\mathbf{1 4 0}$ ]

\begin{tabular}{|c|c|c|c|c|c|c|c|}
\hline \multirow[t]{2}{*}{ S. No. } & \multirow[t]{2}{*}{ Questions } & \multicolumn{2}{|c|}{ Yes } & \multicolumn{2}{|c|}{ No } & \multicolumn{2}{|c|}{ Not sure } \\
\hline & & No. & $\%$ & No. & $\%$ & No. & $\%$ \\
\hline 1 & Objectives of workshop achieved & 135 & 96.42 & o & oo & 5 & 3.57 \\
\hline 2. & Workshop is useful & 140 & 100 & o & oo & o & oo \\
\hline 3. & Active participation of participants & 132 & 94.28 & 2 & 1.42 & 6 & 4.28 \\
\hline 4. & Learning resources are helpful & 130 & 92.85 & o & oo & 10 & 7.14 \\
\hline 5. & Faculties are helpful \&responsive & 134 & $95 \cdot 71$ & 1 & 0.71 & 5 & $3 \cdot 57$ \\
\hline \multirow[t]{2}{*}{6.} & Frequency of workshop needed & 140 & 100 & o & oo & o & oo \\
\hline & & \multicolumn{2}{|c|}{ Too much theory } & \multicolumn{2}{|c|}{$\begin{array}{l}\text { Too much practi- } \\
\text { cal }\end{array}$} & \multicolumn{2}{|c|}{ proportional } \\
\hline \multirow[t]{2}{*}{7.} & balance of theory \& practical & 36 & $25 \cdot 71$ & 14 & 10 & 90 & 64.28 \\
\hline & & \multicolumn{2}{|c|}{ good } & \multicolumn{2}{|c|}{ fair } & \multicolumn{2}{|c|}{ poor } \\
\hline 8. & Time management & 130 & 92.85 & 10 & 7.14 & o & oo \\
\hline 9. & Audio visual & 126 & 90 & 14 & 10 & o & oo \\
\hline 10. & venue & 134 & $95 \cdot 71$ & 6 & 4.28 & o & oo \\
\hline
\end{tabular}


MCQ,OSCE and OSPE, structured oral viva, long case and Mini Clinical Evaluation Exercise. ${ }^{4}$

A study conducted at the B.P. Koirala Institute of Health Sciences, Dharan, Nepal to assess the effectiveness of the medical education workshops, enrolling 92 medical teachers. Results showed that there was a significant gain in the knowledge of participants $(\mathrm{p}<0.001)$ and all the participants $(100 \%)$ agreed upon the training being informative and learned recent advances about assessment. ${ }^{6}$

The four Medical Schools of Nepal conducted study to evaluate the training of medical teachers in Medical Education. It concludes with a post workshop significant improvement in the scores of the participants $(p<0.001)$. The workshop was perceived as high degree of acceptance with most of the topics of the assessment, but $39.4 \%$ expressed that the duration of the workshop was too short. ${ }^{7}$

Neena Vinay Nagdeo and Suresh Chari conducted a study to assess the impact of Basic Workshop for Medical teachers at the NKP Salve Institute of Medical Sciences, Nagpur. Two years after the workshop, Evaluation of teaching learning methodology of each faculty members was done. It was found that $78.04 \%$ faculties started new teaching methodologies and $63.41 \%$ teachers modified their assessment methods by introducing OSPE and OSCE in exam pattern. ${ }^{8}$

A teaching workshop was conducted by the Department of Medical Education at Ankara University School of Medicine for their 150 professors from different disciplines. 100\% participants assessed the course as either good or very good. $82 \%$ of participants gave optimal rating to the topics covered and time management and $100 \%$ recommended that it be attended by all faculty members. ${ }^{9}$

A study conducted by Fareed H. Abdulahad et al. at Hawler Medical University, Erbil, Iraq, deliver a general review of a newly designed teaching course for faculty members of the medical colleges and assesses the participants' feedback. It has been found that a high proportion of the participants rated the most of the sessions were useful, which includes teaching-learning methods $(96.2 \%)$, an ideal lecture (96.2\%), motivation to raise the standard of lecture (92.9\%), principles of lecturing $(92.9 \%)$ and regulations and instructions $(92.6 \%){ }^{10}$

Shahid Jamal et al. conducted a study in the Department of Medical Education, Army Medical College Rawalpindi, Pakistan from 2008 to 2010 . The objective was to assess the response of the participants of medical education workshops. 120 participants attended the workshops and out of them 30$45 \%$ found that hand-outs were very useful. $52-78 \%$ found the PPTs and transparencies as below average. The majority of them replied as these activities were very useful and needed to repeat regularly. ${ }^{11}$
The present study showed that there was a significant gain in the knowledge of participants as shown by their scores in pre and post-test questionnaire in all the workshops and by $\mathrm{P}$ value $[<0.003]$ scores of each workshop, which can be correlated with the above studies.

\section{CONCLUSION}

Post workshop significant enhancement in the knowledge of the participants was noted in the statistical analysis. $100 \%$ participants replied that the workshop was useful and informative. More such workshops with longer duration sessions at regular interval was suggested by participants. Therefore, regular organization of such workshops with addition of new advances in medical education would be highly beneficial to improve teaching-learning skill of medical teachers.

\section{ACKNOWLEDGEMENT}

The authors would like to acknowledge the help and support provided by the Department MET CELL, MGM MC Aurangabad. The authors acknowledge the immense help received from the scholars whose articles are cited and included in references of this manuscript. The authors are also grateful to authors / editors / publishers of all those articles and journals from where the literature for this article has been reviewed and discussed.

\section{Source of Funding -no funding}

Conflict of interest- none stated

\section{Abbreviations:}

- ECE- Early Clinical Exposure

- MCI - Medical Council of India

- MET - Medical Education Technology

- OSCE-Objective Structured Clinical Examination

- OSPE- Objective Structured Practical Examination

\section{REFERENCES}

1. Kamel AM. Role of faculty development programs in improving teaching and learning. Saudi J Oral Sci 2016;3:61-8

2. Singh T, Gupta P, Singh D. Principles of Medical education. 4th ed. New Delhi: Jaypee Publishers; 2013.

3. Nasab M M, Ghazanfari S, Kazeroni A T, Zadeh R A. Medical teachers' attitudes towards educational workshops. Medical Education Journal of Iran Spring. 2002; 1(3): 121-4.

4. Ajay Gaur, Akanksha Bansal, Jyoti Bindal. Impact of basic medical education on medical teachers JMR 2015; 1(3): 95-103 May- June

5. Adkoli B V, Sood R. Faculty development and medical education units in India: A survey. NMJI. 2009; 22(1): 28-32.

6. Baral N, Gautam A, Lamsal M, Paudel BH, Lal Das BK, Aryal M. Effectiveness of teachers' training in assessment techniques: participants' perception. Kathmandu Univ Med J 2011. Jul-Sep; 9(35): 189-92. 
7. Baral N, Paudel BH, Das BK, Aryal M, Das BP, Jha N, et al. An evaluation of training of teachers in medical education in four medical schools of Nepal. Nepal Med Coll J. 2007 Sep; 9(3): 157-61.

8. Nagdeo N V, Chari S. Basic Workshop for Medical Teachers: Effectiveness and Impact. NJIRM. 2014; 5(2): 107-114.

9. Ozyurda F, Dokmeci F, Palaoglu O, Arda B. The Role of Interactive Training Skills Courses in Medical Education at the Ankara University School of Medicine. Teach Learn Med. 2002; 14(3):
189-93.

10. Saleh A M, Shabila N P, Ali S K, Abdulahad F H. Introduction and initial evaluation of a newly designed teaching course for medical faculty members in Erbil, Iraq. Middle East Journal of Family Medicine. 2012 May; 10(4): 38-44.

11. Jamal S, Rana M H, Safdar C A, Khan A, shukr I. Short duration medical education workshops - analysis of participants' response. 2012; 1: 1-4. 